\title{
Yttrium Y 90 Monoclonal Antibody MN-14
}

National Cancer Institute

\section{Source}

National Cancer Institute. Yttrium Y 90 Monoclonal Antibody MN-14. NCI Thesaurus.

Code C2249.

A radioimmunotherapeutic monoclonal antibody $(\mathrm{MN}-14)$ directed against tumorassociated carcinoembryonic antigen (CEA) and chelated to the radioisotope yttrium-90 (Y 90). Yttrium 90 monoclonal antibody MN-14 binds to tumor cell expressing CEA, delivering a cytotoxic dose of beta radiation. ( $\mathrm{NCl04)}$ 